\title{
Identifying fisheries dependent communities in EU coastal areas
}

\author{
Fabrizio Natale $^{\mathrm{a}, *}$, Natacha Carvalho ${ }^{\mathrm{a}}$, Michael Harrop ${ }^{\mathrm{b}}$, Jordi Guillen ${ }^{\mathrm{c}}$, Katia Frangoudes $^{\mathrm{d}}$
}

\author{
${ }^{a}$ European Commission, Joint Research Centre, Institute for the Protection and Security of the Citizen, Maritime \\ Affairs Unit, Italy \\ ${ }^{\mathrm{b}}$ European Commission, Eurostat, Regional Indicators and Geographical Information Unit, Luxemburg \\ ${ }^{c}$ IFREMER, UMR AMURE, Unité d'Economie Maritime, France \\ d Université de Brest, UMR AMURE, IUEM, France \\ *: Corresponding author : Fabrizio Natale, tel.: +39 0332789181 ; email address : fabrizio.natale@irc.ec.europa.eu
}

\begin{abstract}
:
The importance of local communities relying on fisheries is constantly emphasised in the European Union's Common Fishery Policy. Previous studies have analysed fishery employment for the entire EU based on statistical figures aggregated by administrative units at the regional or provincial level. This paper adopts a geographical approach to identify EU coastal communities relying on fisheries using accessibility analysis, principles at the basis of gravity models and disaggregated population and employment statistics. The dependency on fisheries is calculated comparing estimated employment from fisheries at each port with general employment in the areas of accessibility surrounding the port. By considering spatially disaggregated statistics the importance of fishing activities for specific local communities emerges more clearly in respect of previous studies. The map of fisheries dependent coastal communities identifies in 2010, 388 communities, out of 1697, with dependency ratios above $1 \%$. Around $54 \%$ of total fishery employment is estimated in these areas. In terms of policy support, identifying and mapping these local fishing coastal communities is of key importance considering the strong priority assigned by the new European Union's Common Fishery Policy to fishery management at the regional level.
\end{abstract}

\section{Highlights}

Fisheries dependent coastal communities are identified for the entire EU. Gravitation of employment towards fishing ports is used to calculate dependency. $\rightarrow$ Spatial analysis methods allow disaggregating on land available fishery statistics. High dependency ratios emerge more clearly at refined spatial resolution. The proposed methods expand possibilities for regional analyses on fisheries.

Keywords: Fisheries employment ; Coastal communities ; Accessibility ; GIS ; Gravity models 


\section{Introduction}

The fishing and aquaculture sectors often play a crucial role in EU coastal areas and many coastal communities rely on these activities for their income having limited possibilities for economic diversification. The European Commission in the new Common Fishery Policy is committed to actively promote growth and improve employment opportunities in coastal fisheries and aquaculture-dependent communities (European Commission, 2011). This priority is in line with the more general target of the Europe 2020 strategy to reach a ratio of $75 \%$ of employment for the $20-64$ year olds by 2020 .

For a relatively small sector like fisheries, specific policy and fishery management measures in certain regions are required in consideration of the social and economic importance that fleets, and especially small-scale coastal fleets, may play in these regions. This is of particular relevance in order to avoid potential negative impacts of fisheries measures on dependent communities.

Several studies have been aimed at measuring the contribution of fisheries to employment in coastal areas and identifying coastal communities relying on fisheries.

At global level fisheries employment amounts to a total of 50 million persons in the catching sector and 210 million in the processing sector (Teh \& Sumaila, 2011). The estimates by Teh and Sumaila (2011) combine fisheries employment information in 144 countries with a model to assess the contribution of small scale fisheries and population data in low-elevation coastal zones from the Socioeconomic Data Application Centre (McGranahan et al., 2007).

In the EU, the relevance of fisheries employment and the regional dependency on fisheries has been assessed for coastal regions comparing statistics on the employment in the fishery sector and on general employment at provincial (NUTS-3) and at regional (NUTS-2) level (Goulding et al., 1999 and Salz \& Macfadyen, 2007). According to Salz \& Macfadyen (2007), in 2005 the total employment of the fishery sector, including aquaculture, processing and catching activities, amounted to about 407,000 persons representing $0.2 \%$ of total EU employment. Considering only the catching sector the employment was estimated in 187,200 jobs $(0.09 \%$ of total EU total employment).

Given the concentration of the fishing industry, the Edinburgh European Council of December 1992 officially recognized the existence of Areas Dependent on Fishing and the need to give them special attention. On the basis of 1997 data, around 34 areas with a rate of dependency on the sector between $3 \%$ and $15 \%$ were identified at NUTS-3 level and around 30 areas with a rate between $20 \%$ and $60 \%$ at local administrative units level (European Commission, 2001).

Studies on fishery employment for the EU rely on one side on economic data on the performance of the fishing sector collected and assembled through the EU Data Collection Framework (DCF) (European Commission, 2008), and on the other side on official employment statistics available from EUROSTAT at NUTS-3 level. The fishery economic data of the DCF is collected by the Member States (MS) through sampling programs by length classes and main gear and assembled at EU level by the Joint Research Centre by country and fleet segment. This data lacks detailed geographical references to regional, provincial or local administrative units. In the case of biologic and 
transversal data the spatial reference to fishing areas provides a mean to perform spatially explicit bio-economic modeling and to relate fishing effort to fish stocks in specific sea areas. However on the "land side" the high spatial aggregation of economic variables by country hinders at the moment the possibility of performing regional socioeconomic studies with EU coverage.

The need for spatially disaggregated data at more finely defined geographical scale has been in general recognized as important for regional analyses (European Commission, 2012). This need is particularly relevant when considering the socio-economic role of the relatively small EU fishing industry, which is mostly affecting local communities.

The purpose of this paper is to provide a method to overcome the current limitations in data availability for regional socio economic studies for the fisheries sector at EU level. In particular the focus is to analyze fisheries employment at more refined geographic scale and to identify and map coastal communities for which fishing activities are particularly relevant.

As first step we disaggregate spatially, fisheries employment national figures using detailed information on vessels at each port from the Community Fleet Register.

As second step, we refer to a method which combines CORINE land cover with information from a soil sealing layer to produce so-called dasymmetric maps of population densities. (Gallego et al., 2011 and Batista e Silva et al., Unpublished results). The high resolution disaggregated population data provided by these maps is used as proxy to disaggregate general employment from official statistics at regional level.

As third step we use accessibility analysis to define areas of influence of fishing ports (hereafter Fisheries Service Areas or FSA). We follow the approach of gravity models which represent flows of goods and people between locations as being proportional to the relative offer and demand at the place of origin and of destination and inversely proportional to distance. This approach has been applied successfully in many areas of economic geography such as the analysis of international trade, human migration and the definition of areas of influence of commercial centers (Huff, 1963). Recent developments are giving stronger theoretical foundations to the model and providing wider acceptance among economists (Anderson, 2011). In relation to the analysis of labor market, gravity models reflect the tendency of people to gravitate towards job opportunities closer to their place of living. While job opportunities generate an attracting force in respect of residential areas, high distance, low accessibility and long commuting time influence negatively the probability of a person being employed at a given location. More in general the analysis of accessibility in respect of geographical focal points of attraction gives the possibility to define areas of economic influence mirroring human behaviors in a geographical context rather than simply referring to aggregation by administrative units such as provinces or regions. Following this line EUROSTAT defined so called Maritime Service Areas considering the areas of attractiveness and inland influence in respect of focal points of attraction (ports and coastal settlements) along the EU coastline (Trifonov et al., 2011). We extend the same approach considering fishing port as the main point of interest for job opportunities.

As final step we combine the estimate of the expected employment generated by fishing activities at each port and the general employment falling in the boundaries of the areas of influence of the fishing ports. The ratio between the two figures represents the relevance of fishing activities in terms of employment opportunities for the surrounding 
areas and is used as measure for the identification of rate of dependency of coastal communities on fishing activities.

The application of spatial analysis methods to the EU fishery sector gave the possibility to map coastal communities relying on fisheries for the entire EU. This result is important for targeting and assessing the impacts of the Common Fishery Policy that is calling for the adoption specific measures for fishery dependent coastal communities. Further studies may be foreseen by disaggregating spatially more fisheries socio-economic data to look at impacts on the "land side" of fisheries policies at a local and regional scale while maintaining a general EU coverage

\section{Methods}

\subsection{Disaggregation of fishery employment}

Data on fishing ports and on the composition of the EU fishing fleet was obtained from the Community Fleet Register (European Commission DG MARE, 2012). The register includes information on size, main gear, power and port of registration for commercial fishing vessels. The register contains the full history of each vessel indicating changes in the registration and licensing status. By selecting the active vessels with an operating license at a given date it was possible to reconstruct the fleet composition by port over time.

The fleet register provides in some cases coordinates of the fishing ports, however this information is not always accurate and complete. A geo coding exercise was performed to complete and verify the port coordinates using port and country names and references to administrative units. The results of automatic geo coding services provided by Google Earth Pro and coordinates from the World Port Index were compared with declared coordinates in the fleet register and checked for consistency with the distance from the coastline to get the most reliable positions for fishing ports.

An essential assumption in this study is that the port of registration in the fleet register corresponds to the main location on land where the economic activity of the vessel can be related and where employment opportunities are most likely generated. This is important more in general for the possibility of disaggregating economic data from DCF in a more refined spatial resolution. While more detailed spatial data is available at MS level and from logbooks and, for larger vessels, from the Vessel Monitoring System, the fleet register offers a unique opportunity to perform regional socio-economic studies for the entire EU. In order to verify the reliability of this assumption an analysis of the areas of activity of a sample of vessels for one country and year was conducted using anonymous data on the origin and destination of fishing trips and the volume and places of landings.

To get an estimate of the employment generated by the fishing sector at each port a cross-sectional linear model was fitted using the fleet compositions and employment figures at national level between 2004 and 2010 from the Scientific, Technical and Economic Committee for Fisheries (STECF) annual economic reports on the fishing fleet (STECF, 2011). The model, defined by the following equation, is based on a simplified 
relation between employment and three main length vessel length classes independently of time, country and specific characteristics of the vessels (see table 1 for the model summary statistics)

$E=\beta_{1} \cdot v_{1}+\beta_{2} \cdot v_{2}+\beta_{3} \cdot v_{3}($ eq. 1)

Where $E$ is the total national employment for catching activities between 2003 and 2010 , and $v_{1} v_{2}$ and $v_{3}$ are the number of vessels registered as active respectively in the length classes below 12 meters, between 12 and 24 meters and above 24 meters.

The parameters for each vessel length class obtained from the model were applied to the vessels in each port at the beginning of each year to calculate potential employment generated by the fishery sector between 2004 and 2010.

\subsection{Delineation of areas of influence for fishing ports}

The analysis of accessibility was performed to delineate the areas of influence of individual fishing ports. The inputs for the analysis were a point dataset with the location of fishing ports and the Tele-Atlas MultiNnet 2009 data set, which provides comprehensive road and ferry lines information for network analysis and routing applications. The FSA were calculated from these datasets using the ESRIs Arclnfo Network Analyst tool. The tool found the nearest section of the road network to the fishing port as the starting point for the FSA calculation. It then generated for each fishing port a polygon covering all accessible streets and ferry connections within the specified impedance of 25 minutes from the port. A single commuting time of 25 minutes across the EU 27 was used on the basis of The Fourth Survey of Working Conditions, which is indicating that workers in the EU spend on average 21 minutes each way for traveling to and from work.

\subsection{Calculation of reference employment data and comparison with fisheries employment}

Data on employed persons at NUTS-3 level was obtained from official EU statistics on active population and unemployment rates. Missing data in the time series were inputted by linear interpolation.

The NUTS-3 general employment was disaggregated spatially on the basis of the population densities from the high resolution map for Europe (Batista e Silva et al., Unpublished results). The map covering the EU territory (except Greece) gives in raster format for each cell of $100 \times 100$ meters the estimated population counts from original population statistics at commune level from the 2006 national census.

By summing up the population values for each cell falling in the FSA it was possible to calculate the number of people gravitating in the area of accessibility of the corresponding fishing port. In the case of neighboring ports with partially overlapping FSA, population values extracted from cells in the areas of intersection were divided by the number of FSA insisting on the cells. In other words the population of the FSA was 
calculated as the sum of entire cell values for cells falling only in one FSA and of a portion of the cell value for those falling in more than one FSA.

The number of employed people was calculated from the population values in proportion to the ratio between population and employed persons at NUTS-3 level.

In the case of Greece and Cyprus, given the lack of coverage in the EU population map the disaggregation of employment figures at NUTS-3 level was carried out considering a uniform distribution of population on the basis of the surface of the FSA.

Finally, the ratio between potential jobs opportunities generated by the fishing sector against the total employed population gravitating on the fishing ports was used as the measure to express the relevance of fishing activities for the local communities (see figure 1 for an outline of the methodology).

\section{Results}

While major fishing ports were directly geocoded through references in the World Port Index, the geocoding of minor fishing ports in the fleet register was not always possible due to spelling errors or to local names not being included in the reference lists of ports and places. Out of a total of 2,051 ports in the fleet register the geo coding was considered acceptable in 1,756 of cases (86\%). The study although not applicable to all fishing ports in the fleet register covers $79 \%$ of the total number of vessels and $83 \%$ of total gross tonnage of the EU fishing fleet.

The linkage of vessels to the port of registration in the fleet register is a key assumption for allocating the fishery employment to a specific geographical location. To prove the robustness of this assumption a sample of 2,153 vessels from the fleet register and 53,160 fishing trips from logbook data of one MS in one year was analyzed. The results showed that $71 \%$ of vessels had between $100 \%$ and $80 \%$ of their trips leaving or departing from the port of registration. Around $74 \%$ of trips left or arrived at the port of registration or at ports within $10 \mathrm{~km}$ from the port of registration. Around $75 \%$ of the number, $57 \%$ of the quantity and $63 \%$ of the value of landings was at either at the port of registration or at ports within $10 \mathrm{~km}$ from the port of registration. These results prove that overall the pattern of activity of the vessels has a robust linkage with the port of registration. This linkage, as expected, is particularly strong for small and medium size vessels and becoming weaker as vessel size increases.

In 2010 the employment in the fishery sector estimated from the model (eq. 1) for the geo coded ports was of 122,300 jobs representing $82 \%$ of the jobs estimated for the total EU fishing fleet. These jobs were associated for $44.1 \%$ to vessels of length below 12 meters, for $21.0 \%$ to vessels between 12 and 24 meters, and for $34.8 \%$ to vessels above 24 meters.

The FSA defined on the basis of the transport network covered a total area of 710,253 square $\mathrm{km}$ with an average area of 404 square $\mathrm{km}$. 
In 2010 , the population living in these areas amounted to a total of $110,999,640$ persons. Considering the active population and unemployment rates the total employment in the FSA was of $45,843,529$ persons.

Overall the ratio of employment in the fisheries catching sector against the general employment in the FSA was of $0.26 \%$.

The specific ratio for each FSA was below $1 \%$ in 1307 cases, from 1 to $5 \%$ for 295 cases, from 5 to $10 \%$ for 64 cases and above $10 \%$ for 29 cases (figure 3 and 4 ).

A total of 66,621 jobs in the fishing sector (54.4\% of fishing jobs) were generated in ports for which the relevance in respect of the surrounding FSA in terms of employment was above $1 \%$ and 22,767 jobs (18.0\% of fishing jobs) in ports for which the relevance was above $5 \%$.

For 2010 there have been identified in the analysis 83 fishing ports with a high dependency of the employment on the fisheries sector (ports with more than 10 persons employed in the fishing sector and where the direct fishing employment represents more than $5 \%$ of the total jobs in the area). Figure 5 shows the 26 fishing ports having more than 10 persons employed in the fishing sector and in which the relevance of the fishing activities is particularly high (ratio above 10\%). In table 2 there are presented the number of ports by country with more than 10 fishers employed according to their dependency ratio, while in table 1 from the annex it can be seen the details for these 83 ports.

Table 2: Number of ports by fisheries dependency by country in 2010

\begin{tabular}{|l|r|r|r|r|r|}
\hline Country & number of Ports & \multicolumn{1}{l}{1 \% } & $1-5 \%$ & $5-10 \%$ & $>10 \%$ \\
\hline Belgium & 4 & 4 & & & \\
\hline Bulgaria & 12 & 3 & 6 & 3 & \\
\hline Cyprus & 1 & & & 1 & \\
\hline Denmark & 64 & 36 & 20 & 6 & 2 \\
\hline Estonia & 26 & 4 & 7 & 9 & 6 \\
\hline Finland & 6 & 2 & 4 & & \\
\hline France & 35 & 28 & 7 & & \\
\hline Germany & 69 & 51 & 14 & 3 & 1 \\
\hline Greece & 92 & 29 & 44 & 13 & 6 \\
\hline Ireland & 11 & 5 & 5 & 1 & \\
\hline Italy & 228 & 181 & 38 & 6 & 3 \\
\hline Latvia & 8 & & 5 & 3 & \\
\hline Lithuania & 1 & 1 & & & \\
\hline Malta & 17 & 11 & 5 & 1 & \\
\hline Netherlands & 14 & 11 & 3 & & \\
\hline Poland & 8 & 5 & 3 & & \\
\hline Portugal & 26 & 18 & 6 & 2 & \\
\hline Romania & 4 & 3 & & & 1 \\
\hline Slovenia & 2 & 2 & & & \\
\hline Spain & 219 & 154 & 55 & 7 & 3 \\
\hline Sweden & 32 & 14 & 17 & & 1 \\
\hline United Kingdom & 90 & 73 & 12 & 2 & 3 \\
\hline Total & 969 & 635 & 251 & 57 & 26 \\
\hline
\end{tabular}


When looking at the employment dependency of coastal communities on the fisheries sector over time, the fisheries employment dependency decreases between 2004 and 2010 for the EU (on average) and for most EU countries (table 3).

Table 3: Evolution of the fisheries employment dependency ratio by country

\begin{tabular}{lrrrrrrr} 
Country & 2004 & 2005 & 2006 & 2007 & 2008 & 2009 & 2010 \\
\hline Belgium & 0.524 & 0.507 & 0.490 & 0.424 & 0.408 & 0.403 & 0.326 \\
\hline Bulgaria & & & & & 0.642 & 0.669 & 0.766 \\
\hline Cyprus & & 0.632 & 0.536 & 0.540 & 0.812 & 0.982 & 1.142 \\
\hline Denmark & 0.042 & 0.049 & 0.056 & 0.072 & 0.089 & 0.100 & 0.120 \\
\hline Estonia & & 1.009 & 0.905 & 0.769 & 0.715 & 0.752 & 0.404 \\
\hline Finland & 0.580 & 0.550 & 0.507 & 0.476 & 0.473 & 0.496 & 0.507 \\
\hline France & 0.419 & 0.412 & 0.407 & 0.379 & 0.369 & 0.347 & 0.329 \\
\hline Germany & 0.181 & 0.169 & 0.157 & 0.151 & 0.141 & 0.137 & 0.131 \\
\hline Greece & 0.604 & 0.591 & 0.568 & 0.553 & 0.529 & 0.531 & 0.532 \\
\hline Ireland & 0.494 & 0.441 & 0.417 & 0.423 & 0.443 & 0.428 & 0.439 \\
\hline Italy & 0.406 & 0.397 & 0.382 & 0.373 & 0.366 & 0.371 & 0.372 \\
\hline Latvia & & 2.235 & 1.974 & 1.763 & 1.693 & 1.861 & 1.631 \\
\hline Lithuania & & 0.047 & 0.032 & 0.076 & 0.092 & 0.081 & 0.062 \\
\hline Malta & & 0.862 & 0.855 & 0.828 & 0.819 & 0.703 & 0.703 \\
\hline Netherlands & 0.118 & 0.119 & 0.106 & 0.102 & 0.100 & 0.090 & 0.094 \\
\hline Poland & & 0.441 & 0.301 & 0.263 & 0.233 & 0.207 & 0.172 \\
\hline Portugal & 0.519 & 0.519 & 0.329 & 0.312 & 0.304 & 0.299 & 0.280 \\
\hline Romania & & & & 0.018 & 0.074 & 0.063 & 0.096 \\
\hline Slovenia & & 0.318 & 0.313 & 0.328 & 0.333 & 0.346 & 0.348 \\
\hline Spain & 0.442 & 0.408 & 0.378 & 0.363 & 0.356 & 0.363 & 0.347 \\
\hline Sweden & 0.112 & 0.115 & 0.107 & 0.108 & 0.110 & 0.104 & 0.099 \\
\hline United Kingdom & 0.138 & 0.131 & 0.124 & 0.120 & 0.115 & 0.111 & 0.109 \\
\hline Average Total & 0.315 & 0.312 & 0.288 & 0.278 & 0.274 & 0.272 & 0.267 \\
\hline & & & & & & &
\end{tabular}

\section{Discussion}

The fact that in some countries the number of fishing jobs reported in fishery statistics is lower than the number of fishing vessels registered as active is a sign that the fishing fleet is in many cases underutilized. The model which is linking on one side employment from official statistics and fleet consistencies in the fleet register is taking into account of potential underutilization in an averaged way across MSs, years and fleet segments. The under utilization rate and the actual employment associated to a vessel may vary in function of the fishing effort and specific fisheries characteristics such as type of gear used and main species targeted. With the aggregated employment data available at national level it was not possible to fit a more detailed model taking into account these more specific characteristics; therefore employment figures for the fishing sector estimated in this study have to be considered in terms of average employment rather than actual employment linked to specific levels and types of fishing activity. Further research may be foreseen to design a more refined model on the basis of disaggregated 
data and to link employment with the specific characteristics of the fisheries, their level of activity and other economic variables.

This study gives the possibility to identify the fishing communities at the right geographical scale. The definition of FSA is based on the calculation of accessibility using a fixed threshold of 25 minutes of commuting time. The consideration of time instead of Euclidean distance offered a more realistic representation of accessibility and allowed to capture the specific geographical characteristics determining remoteness and isolation which are particularly relevant in the case of fishing ports located on small islands. This threshold although based on statistics on average commuting time would need to be further validated considering empirical evidence specifically for the employment in the fishing sector.

By simplifying the underlying idea behind gravity models the FSA represent accessibility boundaries which indicate in binary terms the existence of potential employment flows towards job opportunities in the fishing ports. This is a simplification of gravity models in two respects: distance is not considered as a continuous variable and the relative importance of origin (populated areas) and destination (fishing ports) are not explicitly used to quantify the intensity of employment flows along all possible combinations of origins and destinations. This simplification is needed for computational reasons given the scale of the study covering the entire EU and justified by the fact that the main aim of the analysis was not so much in assessing relations between specific residential places and fishing ports but to map their areas of influence.

Once defined the areas of accessibility, the relevance of fishing ports in terms of employment opportunities was quantified by the ratio of employment expected from the fishing sector and overall employment conditions in the areas. Instead of comparing the fishery employment with general employment in an administrative region the FSA allowed to consider employment in a closer surrounding and to reflect more realistically geographical features, accessibility and the tendency of people to gravitate towards job opportunities close to their place of living.

With this approach the importance of fishing ports in fisheries dependent communities is emphasized on one side by the presence of a large number of fishing vessels and on the other side by the presence of surrounding areas sparsely populated, with high unemployment rates and poor accessibility. All these factors correspond to well known categories in the definition of disadvantaged regions in regional policies.

In the previous study by Eurostat (REF), the Maritime Service Areas were overlaid with local administrative units and the relevance of costal activities was assessed for the local administrative units in terms of percentage of their surface falling in the Maritime Service Areas. Population affected by the Maritime Service Areas was than estimated proportionally to this overlapping surface considering uniform density distributions from census data. In this study the perspective is reversed and what is measured is the relevance of each FSA on the basis of the size of employment generated by the fishing ports in comparison to the population - and associated employment - gravitating in the FSA. This reversing of perspective represents a shift from an administrative reference in the consideration of statistics and economic relevance towards a geographical one. Instead of using predefined geometries based on administrative boundaries, areas of influence are drawn considering accessibility and the reference population is captured 
using a more precise disaggregation method based on the land cover ancillary information rather than a uniform density distribution. A consequence of considering overlapping FSA instead of spatially separate administrative units is that the population groups in the areas of intersection may be gravitating at the same time towards several fishing ports. The double counting of reference population data would bring to an underestimation of the relevance in the case of neighboring fishing ports with overlapping FSA. To address this issue the population counts from the areas of intersections were divided in equal parts among the relative fishing areas letting people gravitate exclusively towards one of the overlapping fishing ports. This corresponds again to a simplified application of a gravity model in which equal probabilities are applied to determine the shares of population migrating towards competing focal points of attraction independently from specific distance and size of the connected population centers and focal points.

Previous studies (REF) indicate a rate of contribution of $0.09 \%$ from the catching sector to EU general employment in 2005. In this study it is estimated that in 2010 the overall relevance of the fisheries employment in respect of general employment in the surrounding FSA was of $0.27 \%$. This result is in line with estimates considering figures at regional and provincial (NUTS2 - NUTS3) level. This increase in the importance of the fisheries sector to create employment is not due to an increase over time of the fisheries sector importance, but on a more precise geographical level. Previous studies show the fisheries employment in the overall EU economy, while this study focuses on the analysis of coastal communities, and so on investigating the existence of fisheries dependent areas. In fact, as can be seen from table 3 , the significance of fisheries as a creator of employment in coastal communities has decreased.

Figure 3 shows the geographical distribution of the fishery dependent communities. From the figure it can be seen a major dependency of communities on fisheries in the northern area of the EU, while one could initially expect southern (Mediterranean) communities to be more dependent. This can be explained by the existence of large populated areas along the Mediterranean coast together with good transport infrastructures which imply that most fishing ports are not distant from populated centers.

Since fishery employment is estimated from the fleet structure it is possible to assess the relevance of fishing ports separately for each vessel length category and, in this way, to consider separately local impacts deriving from the different types of employments. It is therefore possible to monitor and analyze the impact of different management measures on the coastal communities, and in particular on the ones with a high dependence on the fisheries sector. For example, if an hypothetic introduction of ITQs (or some sort of individual property rights) would lead to a concentration of the sector and consequently a reduction of the artisanal fleet this will also affect the coastal communities on a different degree depending on the importance of the artisanal fleet in the employment creation of each community.

\section{Conclusions}

The innovation of this study is in the adoption of spatial methods and a geographical perspective rather than an administrative perspective for estimating contribution of fisheries to local economies at an EU scale. This approach allowed to identify and map 
specific local communities in which given the conditions of accessibility, employment and size of the fishing fleet the dependence from fishing activities can be considered particularly relevant with ratios of employment in the fishing sector against general employment above 1\%. Monitoring these communities, or a sample of them, would help to analyze the socio-economic effects of different fishery policies in these particularly sensible areas. Furthermore, these communities merit specific policy actions aimed at preserving job opportunities in the fishing sector as underlined by the undergoing reform of the EU Common Fishery Policy.

\section{References}

Anderson, J. (2011) The gravity model. Annual Review of Economics 3, 133-160.

Batista e Silva, F., Gallego, F. J. \& Lavalle, C. (Unpublished results) A high resolution population grid map for Europe.

European Commission (2001) Second report on economic and social cohesion. http://ec.europa.eu/regional_policy/sources/docoffic/official/repor_en.htm (accessed September 2012).

European Commission (2008) Regulation (EC) No 665/2008. Official Journal L 186/3.

European Commission (2011) Reform of the Common Fishery Policy COM(2011) 417.

European Commission (2012) Fifth report on economic, social and territorial cohesion. http://ec.europa.eu/regional_policy/sources/docoffic/official/repor_en.htm (accessed September 2012).

European Commission DG MARE (2012) Community Fishing Fleet Register. http://ec.europa.eu/fisheries/fleet/index.cfm (accessed March 2012).

Gallego, F., Batista, F., Rocha, C. \& Mubareka, S. (2011) Disaggregating population density of the European Union with CORINE land cover. International Journal of Geographical Information Science 25, 2051-2069.

Goulding, I., Hallamm, D., Harrison-Mayfield, L., Mackenzie-Hill, V. \& da Silva, H. (1999) Regional Socio-economic Studies on Employment and the Level of Dependency on Fishing. Lot No.23: Coordination and Consolidation Study, 113 pp.

Huff, D. L. (1963) A Probabilistic Analysis of Shopping Center Trade Areas. Land Economics 39, 81-90.

McGranahan, G., Balk, D. \& Anderson, B. (2007) The rising tide: Assessing the risks of climate change and human settlements in low elevation coastal zones. Environment and Urbanization 19, 17-37.

STECF (2011) The 2011 Annual Economic Report on the EU Fishing Fleet. STECF-1116, 233 pp. JRC Scientific and Technical Report. Luxembourg?? 
Salz, P. \& Macfadyen, G. (2007) Regional dependency on fisheries. IP/B/PECH/ST/IC/2006-198 http://www.framian.nl/our_publications/ (accessed September 2012), $162 \mathrm{pp}$.

Teh, L. \& Sumaila, U. (2011) Contribution of marine fisheries to worldwide employment. Fish and Fisheries doi:10.1111/j.1467-2979.2011.00450.x.

Trifonov, A., Willadsen, T. \& Collet, I. (2011) Maritime service areas. Highlighting the impact of coastal maritime activities on the hinterland. Eurostat Statistics in focus 41.

\section{Tables}

Table 1 : Model for the estimation of fishery employment

\begin{tabular}{lll}
\hline & Coefficient & s.e. \\
\hline$\beta_{1}$ & 1.0875 & $(0.07498)$ \\
$\beta_{2}$ & 2.8084 & $(0.37234)$ \\
$\beta_{3}$ & 16.1393 & $(1.28849)$ \\
R-squared & 0.9684 & \\
$F(3,122)$ & 1248 & \\
$p$-value & $<2.2 \mathrm{e}-16$ & \\
\hline
\end{tabular}




\section{Figures}

Figure 1: Outline of the methodology of the study. Detailed information in the fleet register is used to estimate fishery employment at each fishing port disaggregating spatially national figures available through the EU"s DCF. The Fishing Service Areas are defined by considering the transport network and the threshold of 25 minutes of travelling time from fishing ports. The reference general employment in these areas is calculated extracting population counts from the population grid at 100x100 meters resolution. Finally the relevance of fishing ports is determined as ratio of estimated fishery employment and reference employment in the respective Fishing Service Area.

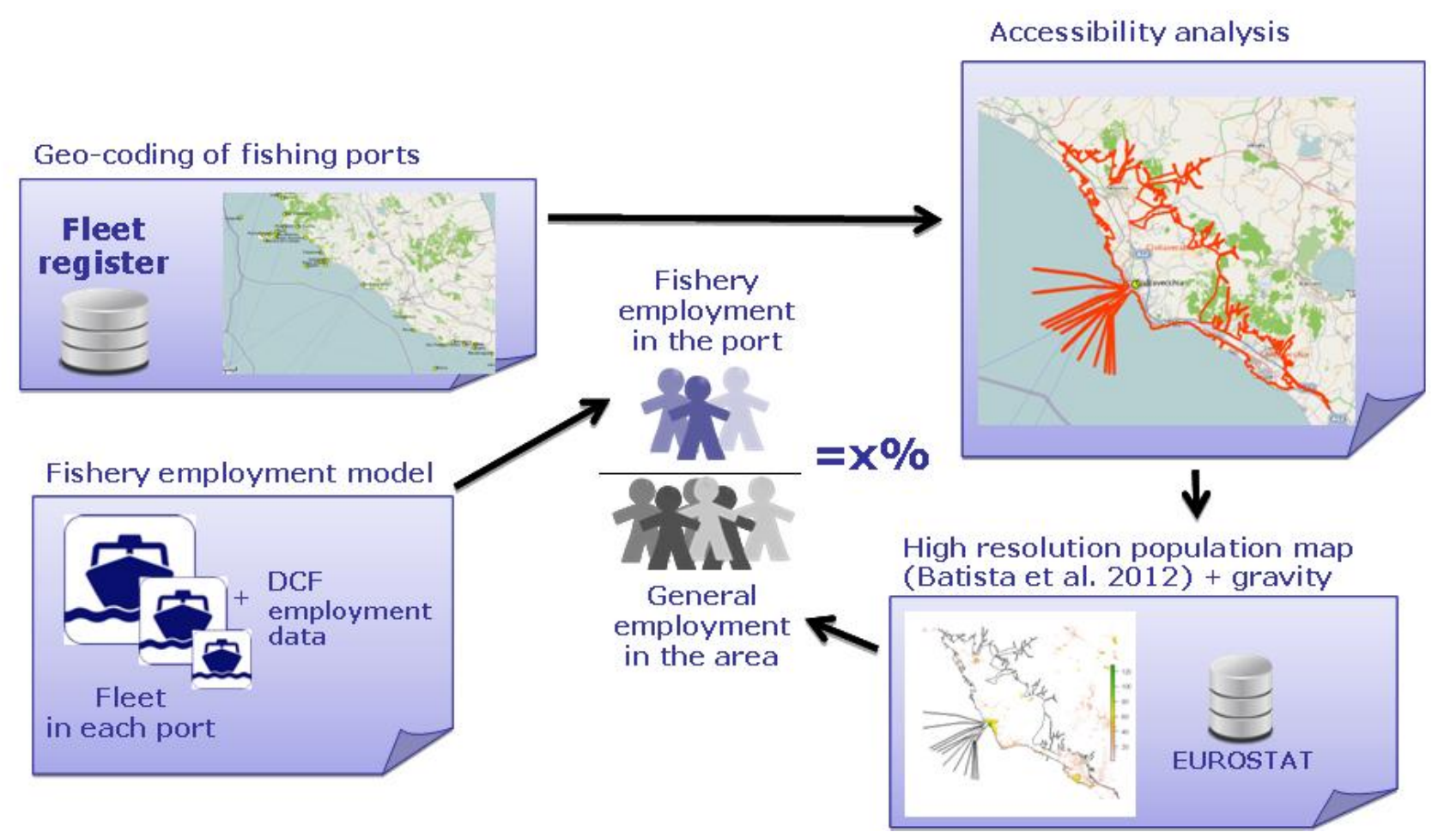


Figure 2 : Pattern of activity for a sample of vessels for one MS and one year from the fleet register, and trips from log book data. The charts show that most vessel have $100 \%$ of trips leaving or arriving at the port of registration, (upper left) and that most of the trips (lower left), $\mathrm{nr}$ of landings (upper right) and to lesser extend the value of landings (lower right) are linked either at the port of registration or other ports within few $\mathrm{km}$ form the port of registration.

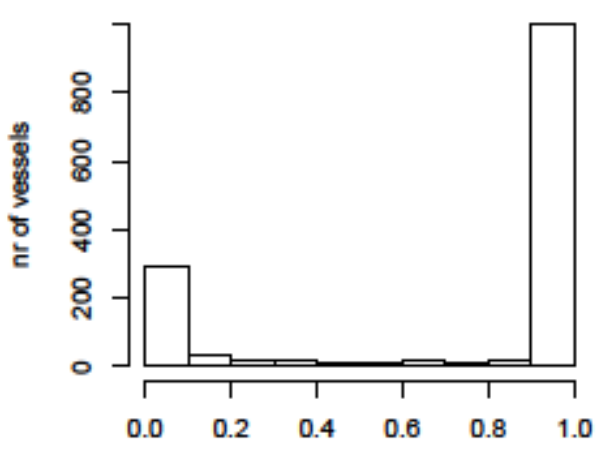

share of trips within $10 \mathrm{~km}$ from port of registration
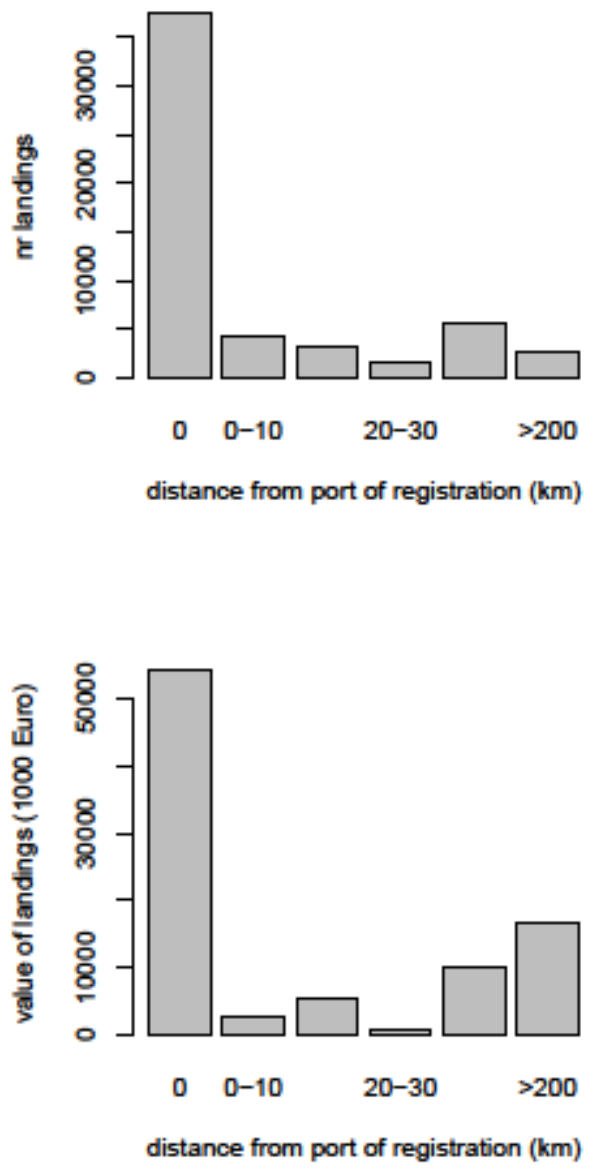
Figure 3: Fishing Service Areas were defined for 1,756 fishing ports representing around $80 \%$ of the fishery sector of the EU. Local communities relying on fisheries were identified using the ratio between estimated fishery employment and reference employment in the respective fisheries service areas. Proportional symbols and labels are plotted for fisheries service areas with a ratio above $5 \%$.

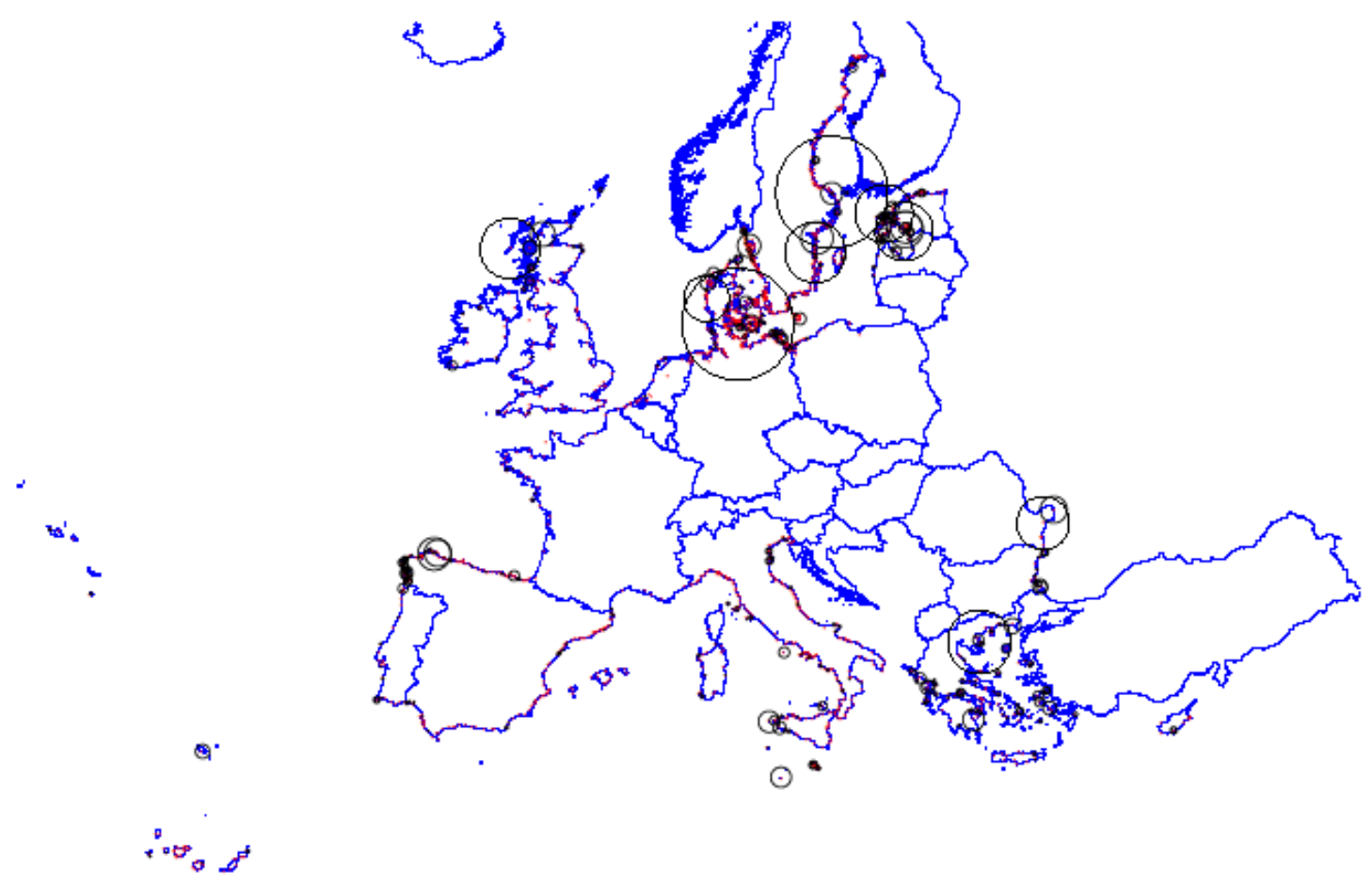


Figure 4 : Number of fishing ports (left) and corresponding values of employment in the fishery sector (right) by relevance of the surrounding service areas. Around $53 \%$ of fishing jobs are generated in areas where fishery employment represents more than $1 \%$ of total employment.
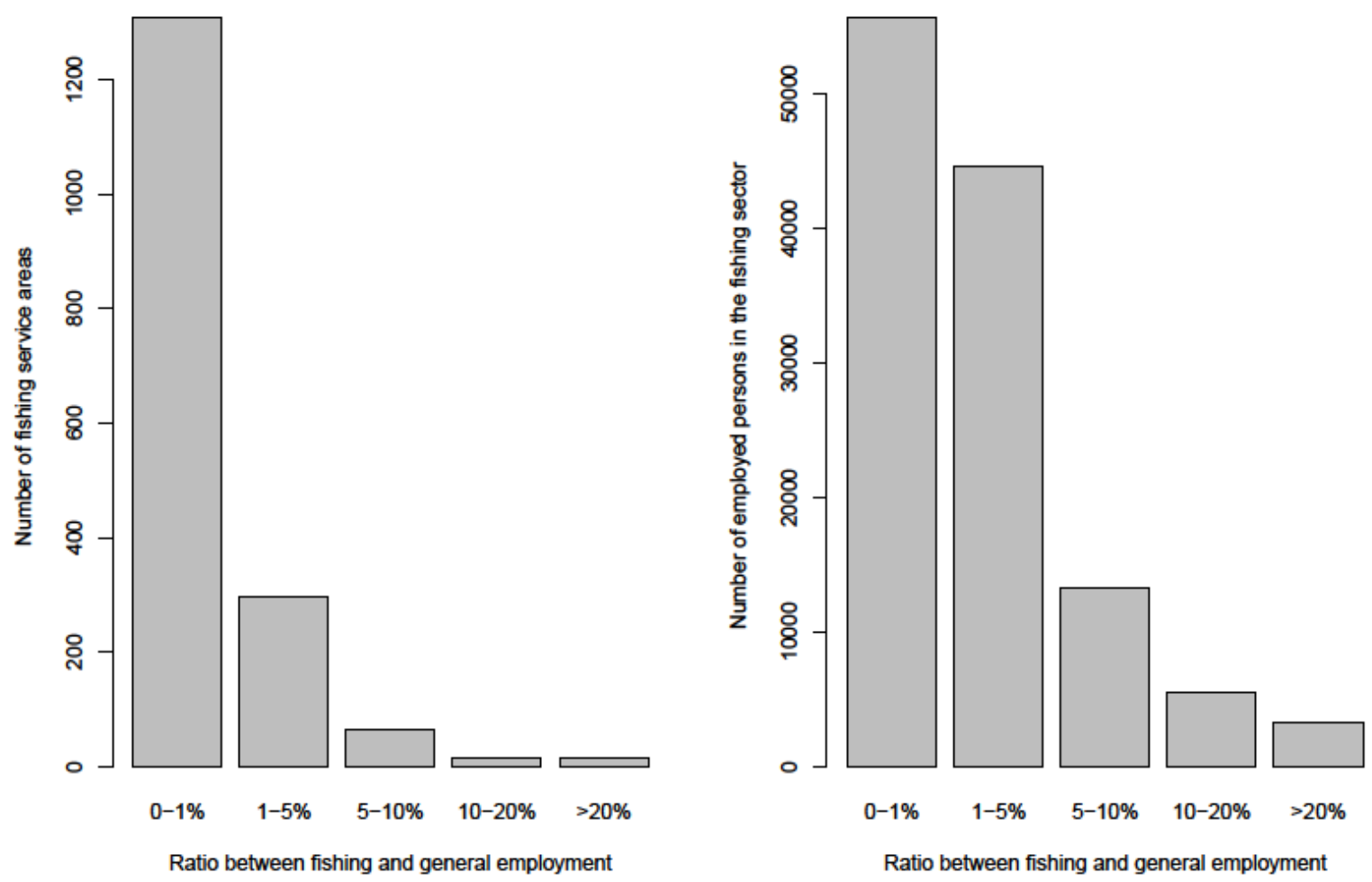
Figure 5 : Fishing ports for which the generated employment represents more than $10 \%$ of total employment in the surrounding service areas. Local communities around these fishing ports can be considered highly dependent on fishing activities.

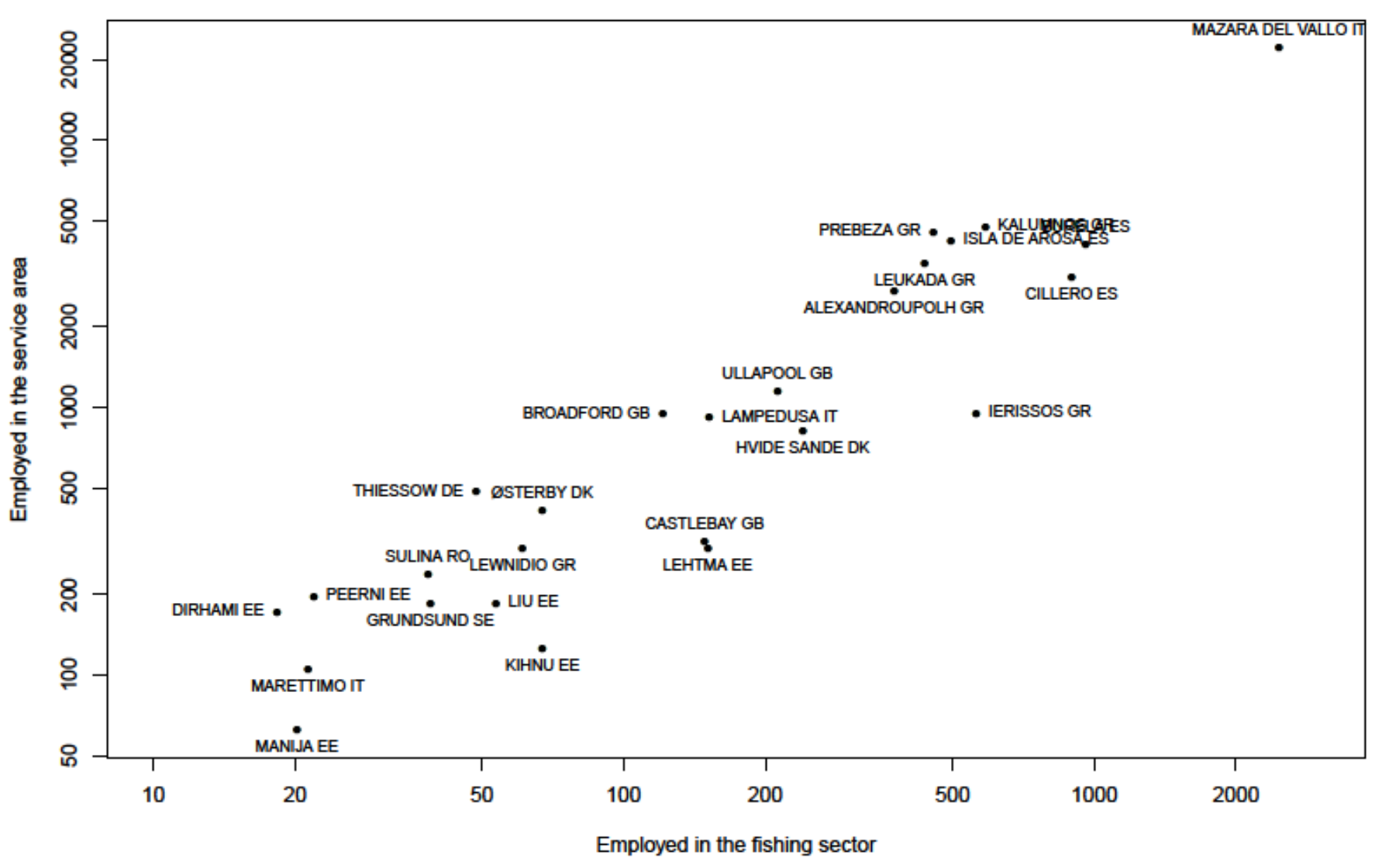




\section{Annex}

Table 1: EU ports with a fisheries employment dependency ratio higher than $5 \%$ and more than 10 fishers in 2010

\begin{tabular}{|c|c|c|c|c|}
\hline name & country & $\begin{array}{l}\text { Fisheries } \\
\text { employment }\end{array}$ & $\begin{array}{l}\text { Total } \\
\text { employment }\end{array}$ & $\begin{array}{l}\text { Dependency } \\
\text { ratio }\end{array}$ \\
\hline IERISSOS & Greece & 560 & 949 & 58.97 \\
\hline KIHNU & Estonia & 67 & 126 & 53.43 \\
\hline LEHTMA & Estonia & 151 & 298 & 50.69 \\
\hline CASTLEBAY & United Kingdom & 149 & 313 & 47.42 \\
\hline MANIJA & Estonia & 20 & 62 & 32.66 \\
\hline HVIDE SANDE & Denmark & 240 & 817 & 29.41 \\
\hline CILLERO & Spain & 895 & 3079 & 29.06 \\
\hline LIU & Estonia & 53 & 185 & 28.86 \\
\hline BURELA & Spain & 959 & 4087 & 23.47 \\
\hline GRUNDSUND & Sweden & 39 & 185 & 20.99 \\
\hline LEWNIDIO & Greece & 61 & 295 & 20.64 \\
\hline MARETTIMO & Italy & 21 & 104 & 20.45 \\
\hline ULLAPOOL & United Kingdom & 212 & 1142 & 18.58 \\
\hline LAMPEDUSA & Italy & 152 & 914 & 16.60 \\
\hline$\tilde{A} \sim$ STERBY & Denmark & 67 & 413 & 16.23 \\
\hline SULINA & Romania & 38 & 238 & 16.11 \\
\hline ALEXANDROUPOLH & Greece & 375 & 2729 & 13.74 \\
\hline BROADFORD & United Kingdom & 121 & 945 & 12.81 \\
\hline LEUKADA & Greece & 436 & 3432 & 12.70 \\
\hline KALUMNOS & Greece & 586 & 4729 & 12.40 \\
\hline ISLA DE AROSA & Spain & 495 & 4203 & 11.79 \\
\hline MAZARA DEL VALLO & Italy & 2469 & 22021 & 11.21 \\
\hline PEERNI & Estonia & 22 & 196 & 11.17 \\
\hline DIRHAMI & Estonia & 18 & 172 & 10.68 \\
\hline THIESSOW & Germany & 48 & 483 & 10.05 \\
\hline PREBEZA & Greece & 455 & 4542 & 10.02 \\
\hline NASVA & Estonia & 127 & 1293 & 9.82 \\
\hline PARGA & Greece & 35 & 355 & 9.79 \\
\hline STRATWNI & Greece & 43 & 452 & 9.59 \\
\hline EL GROVE & Spain & 223 & 2349 & 9.48 \\
\hline PONZA & Italy & 96 & 1050 & 9.16 \\
\hline PATMOS & Greece & 96 & 1051 & 9.13 \\
\hline FOURNOI & Greece & 95 & 1038 & 9.11 \\
\hline BERMEO & Spain & 835 & 9305 & 8.97 \\
\hline MOUDROS & Greece & 47 & 529 & 8.85 \\
\hline FAVIGNANA & Italy & 42 & 484 & 8.65 \\
\hline MERSRAGS & Latvia & 39 & 455 & 8.61 \\
\hline LINDI & Estonia & 59 & 684 & 8.57 \\
\hline LA GUARDIA & Spain & 870 & 10402 & 8.36 \\
\hline SKIBBEREEN & Ireland & 621 & 7435 & 8.35 \\
\hline
\end{tabular}




\begin{tabular}{|c|c|c|c|c|}
\hline GAGER & Germany & 45 & 544 & 8.20 \\
\hline TZAREVO & Bulgaria & 126 & 1562 & 8.08 \\
\hline LIPARI & Italy & 201 & 2492 & 8.08 \\
\hline JAAGUPI & Estonia & 29 & 376 & 7.81 \\
\hline NEUENDORF H & Germany & 17 & 221 & 7.67 \\
\hline VIGO & Spain & 1955 & 25891 & 7.55 \\
\hline TARBERT & United Kingdom & 71 & 940 & 7.54 \\
\hline KÃ „RDLA & Estonia & 34 & 448 & 7.52 \\
\hline VERGI & Estonia & 14 & 188 & 7.51 \\
\hline MGARR & Malta & 211 & 2816 & 7.51 \\
\hline ITEA & Greece & 94 & 1273 & 7.42 \\
\hline FINISTERRE & Spain & 147 & 2013 & 7.29 \\
\hline SAMOS & Greece & 276 & 3808 & 7.26 \\
\hline AHTOPOL & Bulgaria & 75 & 1037 & 7.24 \\
\hline SHABLA & Bulgaria & 116 & 1618 & 7.19 \\
\hline NEXÃ & Denmark & 82 & 1147 & 7.13 \\
\hline MUROS & Spain & 252 & 3547 & 7.10 \\
\hline KÃ・RGESSAARE & Estonia & 23 & 328 & 6.88 \\
\hline OBAN & United Kingdom & 294 & 4386 & 6.70 \\
\hline NAXOS & Greece & 254 & 3812 & 6.67 \\
\hline SEJERÃ ${ }^{\sim}$ & Denmark & 12 & 173 & 6.64 \\
\hline GORO & Italy & 441 & 6867 & 6.42 \\
\hline HANSTHOLM & Denmark & 254 & 4033 & 6.30 \\
\hline FUNCHAL & Portugal & 292 & 4733 & 6.17 \\
\hline LIMASSOL & Cyprus & 1268 & 20588 & 6.16 \\
\hline OURANOUPOLH & Greece & 25 & 424 & 5.90 \\
\hline SALINÃ•MME & Estonia & 24 & 408 & 5.86 \\
\hline KERKURA & Greece & 657 & 11294 & 5.81 \\
\hline SKUROS & Greece & 62 & 1069 & 5.80 \\
\hline CAMARIÃ,AS & Spain & 109 & 1898 & 5.76 \\
\hline STULIDA & Greece & 288 & 5058 & 5.70 \\
\hline THYBORÃ̃N & Denmark & 191 & 3400 & 5.61 \\
\hline CHIOGGIA & Italy & 959 & 17220 & 5.57 \\
\hline$S \tilde{S A} \cdot R U$ & Estonia & 11 & 197 & 5.52 \\
\hline SALACGRIVA & Latvia & 76 & 1397 & 5.42 \\
\hline ROJA & Latvia & 124 & 2298 & 5.39 \\
\hline BAGENKOP & Denmark & 39 & 729 & 5.38 \\
\hline VIRTSU & Estonia & 28 & 524 & 5.31 \\
\hline SKAGEN & Denmark & 145 & 2730 & 5.31 \\
\hline SASSNITZ & Germany & 112 & 2122 & 5.28 \\
\hline PORTOFERRAIO & Italy & 125 & 2420 & 5.15 \\
\hline SAGRES & Portugal & 143 & 2830 & 5.07 \\
\hline RODOS & Greece & 348 & 6873 & 5.06 \\
\hline Total $>5 \%$ & & 21987 & 251274 & 8.75 \\
\hline Total & & 119812 & 34506678 & 0.35 \\
\hline
\end{tabular}

